Foss. Rec., 24, 445-453, 2022

https://doi.org/10.5194/fr-24-445-2022

(C) Author(s) 2022. This work is distributed under

the Creative Commons Attribution 4.0 License.

\title{
The first xiphydriid wood wasp in Cretaceous amber (Hymenoptera: Xiphydriidae) and a potential association with Cycadales
}

\author{
Jia Gao ${ }^{1}$, Michael S. Engel ${ }^{2,3}$, Friðgeir Grímsson ${ }^{4}$, Lei Gu ${ }^{1}$, Dong Ren ${ }^{1}$, and Tai-Ping Gao ${ }^{1}$ \\ ${ }^{1}$ College of Life Sciences and Academy for Multidisciplinary Studies, Capital Normal University, \\ 105 Xisanhuanbeilu, Haidian District, Beijing 100048, China \\ ${ }^{2}$ Division of Entomology, Natural History Museum, and Department of Ecology \& Evolutionary Biology, \\ University of Kansas, 1501 Crestline Drive - Suite 140, Lawrence, KS, 66045-4415, USA \\ ${ }^{3}$ Division of Invertebrate Zoology, American Museum of Natural History, Central Park West at 79th Street, \\ New York, NY, 10024-5192, USA \\ ${ }^{4}$ Department of Botany and Biodiversity Research, University of Vienna, Rennweg 14, 1030 Vienna, Austria
}

Correspondence: Michael S. Engel (msengel@ku.edu) and Tai-Ping Gao (tpgao@cnu.edu.cn)

Received: 20 August 2021 - Revised: 17 November 2021 - Accepted: 17 November 2021 - Published: 4 January 2022

\begin{abstract}
A new genus and species of fossil wood wasp is described and figured from mid-Cretaceous Kachin amber, representing the first occurrence of the family Xiphydriidae in the fossil record. Paraxiphydria resinata gen. et sp. nov. exhibits typical apomorphies of the family including a generally cylindrical body, elongate neck and dome-shaped head. Nonetheless, owing to a unique combination of traits including features hitherto unknown among species of the family, the genus is classified within a separate subfamily, Paraxiphydriinae subfam. nov. A key is presented to the suprageneric groups of Xiphydriidae. The newly described species is the first fossil xiphydriid wood wasp, extends the occurrence of Xiphydriidae into the mid-Cretaceous and adds to the known diversity of features in the family. Lastly, the simplification of wing venation and hypotheses of host-plant affiliations of early xiphydriids are discussed. We evaluate pollen associated with the wasp, assign it to the genus $C y$ cadopites and conclude that an affiliation to the Cycadales is most likely. Article and nomenclatural acts are registered in ZooBank (http://zoobank.org/, last access: 15 December 2021), with the following life science identifier (LSID) (reference): urn:lsid:zoobank.org:pub:DA80920E-E94B-4A8EA817-077FA7BD7D69.
\end{abstract}

\section{Introduction}

Wood wasps of the family Xiphydriidae are a distinctive lineage of approximately 165 species, most often recognized as the sister group to the Euhymenoptera (Orussoidea + Apocrita) (Vilhelmsen, 2001; Sharkey et al., 2012; Aguiar et al., 2013; Malm and Nyman, 2015), although they have at times been included in the Siricoidea, alongside Siricidae and Anaxyelidae or just Siricidae (e.g., Taeger et al., 2010). Recent molecular phylogenies have suggested an alternative arrangement, with reciprocally monophyletic basal Eusymphyta Peters et al. (Xyeloidea + Pamphilioidea + Tenthredinoidea) and Unicalcarida Schulmeister et al. (= all other clades) (Peters et al., 2017). Under this estimate of relationships, Siricoidea and Xiphydrioidea were sisters (i.e., clade Xylosymphyta Engel) and sisters to a clade comprising Cephoidea + Euhymenoptera (Peters et al., 2017). Clearly, relationships among these groups remain controversial, and more extensive analyses are needed with broader suites of data and taxon sampling, including paleontological evidence, before robust resolution of basal Hymenoptera, including the position of Xiphydriidae, may be achieved. 
Modern species of Xiphydriidae are most easily recognized by their characteristically cylindrical bodies and their elongate necks bearing a typically dome-shaped head, although other characters for the family include the following: long, filiform antennae with 14-23 flagellomeres; lateral lobes of mesoscutum typically divided by transverse ridge; mesopostnotum not visible (i.e., mesoscutum and mesoscutellum together); single protibial spur, cleft apically; and hind wing with closed cells (Benson, 1954; Smith, 1988). Extant Xiphydriidae are divided into two subfamilies, Xiphydriinae and Derecyrtinae, according to whether the pronotal collar is deeply excavated anteriorly and whether there is a dorsal area margined by a carina and including a prominent tubercle near the mesoscutellar apex (Benson, 1954; Riek, 1955). Derecyrtinae are restricted to Central and South America except for the monotypic genus Austrocyrta Riek from Australia (Riek, 1955), while Xiphydriinae occur worldwide (Maa, 1949; Jennings et al., 2007).

Xiphydriid larvae bore through the dead or dying wood of angiosperm trees and shrubs, where they feed on associated xylophagous fungi. Where known, adult females inoculate the wood with fungal spores stored in a mycangium, much like Siricidae (Kajimura, 2000). Hitherto, the family has not been documented in the fossil record. Here we describe the first fossil xiphydriid wood wasp from a female preserved in mid-Cretaceous Kachin amber. The specimen is well preserved, allowing for an examination of nearly all pertinent characters. The species is placed in a new genus and subfamily, and a key is provided to the suprageneric groups of Xiphydriidae.

\section{Materials and methods}

The type specimen was collected from Kachin (Hukawng Valley) in northern Myanmar, deposits of which were dated at $98.79 \pm 0.62 \mathrm{Ma}$ (Cruickshank et al., 2003; Shi et al., 2012; Yu et al., 2019). The amber specimen described herein is housed in the Key Laboratory of Insect Evolution and Environmental Changes, College of Life Sciences and Academy for Multidisciplinary Studies, Capital Normal University, Beijing, China (CNUB; curator: Dong Ren). The specimen was examined with a Leica M205C dissecting microscope (DM), and photographs were taken with a Nikon SMZ 25 and Nikon ECLIPSE Ni, each with and an attached Nikon DS-Ri2 digital camera system. The pollen grains were also studied using a Zeiss LSM 780 inverted confocal laser microscope (CLM) equipped with a $20 \mathrm{X} \mathrm{ob-}$ jective and $488 \mathrm{~nm}$ laser. Pollen terminology follows Punt et al. (2007) and Halbritter et al. (2018). Line drawings were prepared and arranged in Adobe Illustrator CC and Adobe Photoshop CC graphics software. Wing venation nomenclature loosely follows that of Rasnitsyn $(1969,1980)$, with the following abbreviations: $\mathrm{A}$, anal vein; $\mathrm{C}$, costal vein; $\mathrm{Cu}$, cubital vein; $\mathrm{M}$, median vein; $\mathrm{R}$, radial vein; $\mathrm{R} 1$, first radial;
Rs, radial sector; 1 cu-a, crossvein between $1 \mathrm{Cu}$ and $\mathrm{A}$; 2rs$\mathrm{m}$ and 3rs-m, crossveins between Rs and $\mathrm{M}$; and $1 \mathrm{~m}$-cu and $2 \mathrm{~m}-\mathrm{cu}$, crossveins between $\mathrm{M}$ and $1 \mathrm{Cu}$.

\section{Systematic paleontology}

Order Hymenoptera Linnaeus

Family Xiphydriidae Leach

Paraxiphydriinae J. Gao, Engel, \& T. Gao, subfam. nov. urn:lsid:zoobank.org:act:7463861B-0BE2-4379-88D302D1F9E34A6E

\section{Type genus}

Paraxiphydria, J. Gao, Engel, \& T. Gao, gen. nov.

\section{Diagnosis}

The new subfamily can be distinguished most readily from other lineages of Xiphydriidae by the absence of 1r-rs and 2 rs- $m$ in the forewing, as well as the exceptionally short $2 \mathrm{M}$ in the forewing, which is scarcely present owing to the proximal position of $1 \mathrm{~m}$-cu near the origin of 2 Rs. In the hind wing, cell $r$ is open, and 3rs-m and $1 \mathrm{~m}-\mathrm{cu}$ are absent. The open hind wing cell $r$ is likely plesiomorphic (symplesiomorphic with Siricoidea and Orussoidea), and the closed cell $r$ is like Xiphydriinae and Derecyrtinae and is a putative synapomorphy uniting these two subfamilies relative to Paraxiphydriinae. In addition, the anterior margin of the pronotal collar is comparatively straight, while in most extant Xiphydriidae this margin exhibits varying degrees of convexity, although a few species are nearly straight (e.g., some Derecyrta Smith). The tarsi lack pulvilli (= plantulae, although historically referred to as pulvilli in the xiphydriid literature, these are technically plantulae), a feature that differs from most Xiphydriidae except some species of Derecyrta, which have secondarily lost the pulvilli. The maxillary palpus is pentamerous, the likely plesiomorphic condition for the family.

The classification of Benson (1954) is followed and emended here, with Maoxiphinae Maa, Hyperxiphinae Maa and Euxiphydriinae Maa (Maa, 1949) all being synonyms of Xiphydriinae. The following key aids the recognition of the new subfamily, as well as the remaining subfamilies and tribes.

\section{Key to subfamilies and tribes of Xiphydriidae}

1 Forewing with 1r-rs and 2rs-m present; $2 \mathrm{M}$ distinct, as long as or longer than $2 \mathrm{Rs}$, rarely slightly shorter than 2Rs; hind wing cell $\mathrm{r}$ closed; hind wing $3 \mathrm{rs}-\mathrm{m}$ and $1 \mathrm{~m}-$ cu present; anterior margin of pronotal collar concave: 2

- Forewing with 1r-rs and 2rs-m absent; $2 \mathrm{M}$ exceptionally short, scarcely present owing to proximal position 

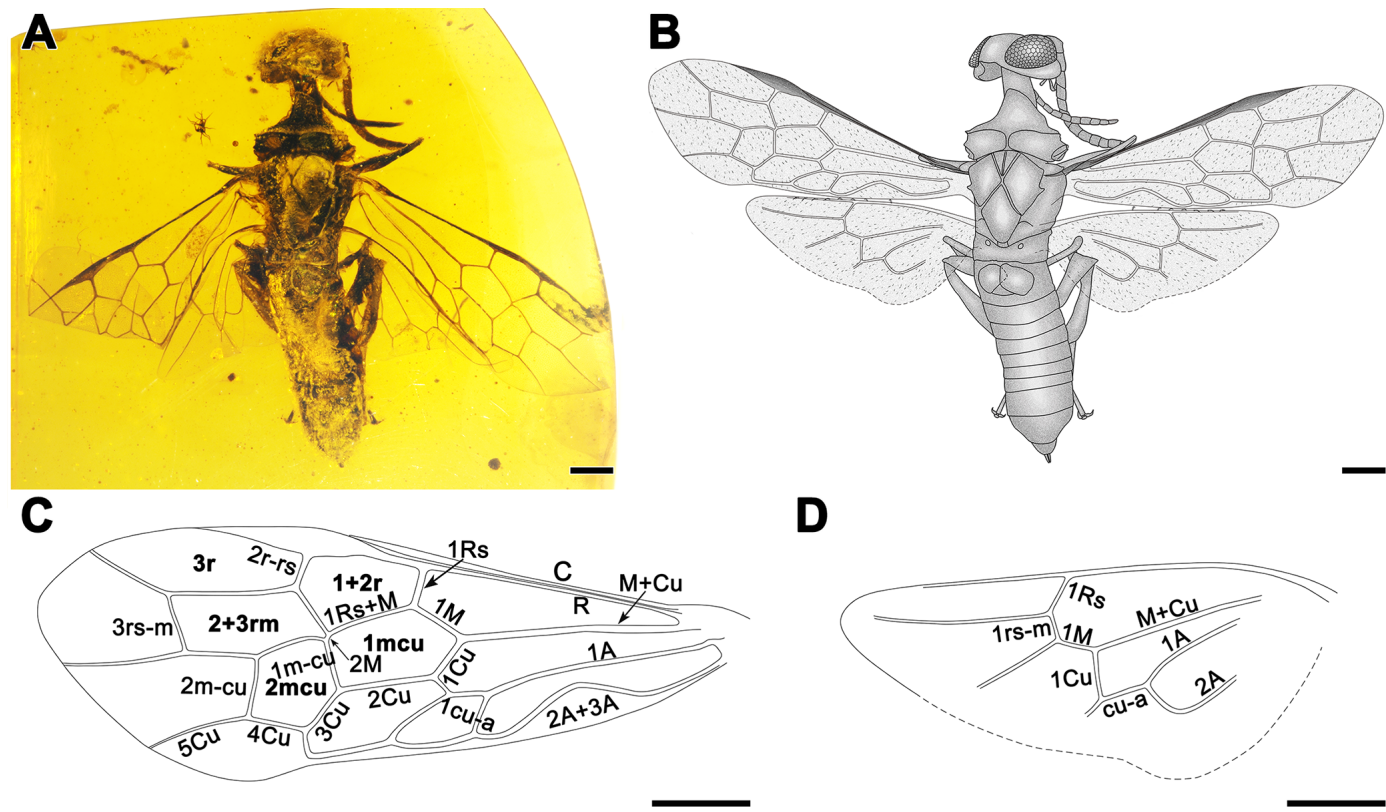

D

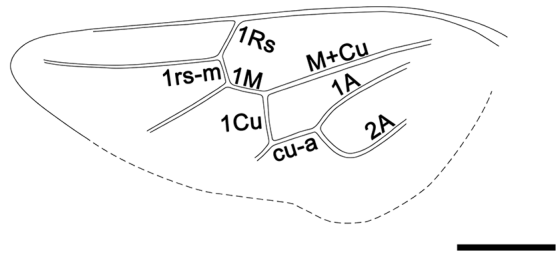

Figure 1. Paraxiphydria resinata gen. et sp. nov. holotype. (a) Photograph of habitus in dorsal view. (b) Line drawing in dorsal view. (c) Line drawing of left forewing. (d) Line drawing of left hind wing. Scale bars: $0.5 \mathrm{~mm}$ (a-d).

of $1 \mathrm{~m}-\mathrm{cu}$; hind wing cell $\mathrm{r}$ open; hind wing 3rs-m and $1 \mathrm{~m}-\mathrm{cu}$ absent; anterior margin of pronotal collar comparatively straight: Paraxiphydriinae, subfam. $n$.

2(1) Pronotal collar with mediodorsal length long, more than tegular length, excavation of anterior margin about equal to mediodorsal length; mesoscutellum with dorsal area margined by carina, typically with a prominent tubercle apically; metapretarsal claw of female enlarged, $1.5 \times$ or greater than length of mesopretarsal claw; ovipositor sheaths $0.50-0.65 \times$ length of basal plate; tarsi with or without pulvilli (subfamily Derecyrtinae Ashmead): 3

- Pronotal collar with mediodorsal length short, shorter than tegular length, excavation of anterior margin much greater than mediodorsal length; mesoscutellum without dorsal area defined by carina, lacking tubercle apically; metapretarsal claw of female not enlarged, similar to mesopretarsal claw; ovipositor sheaths $0.65-1.0 \times$ length of basal plate; tarsi with pulvilli: Xiphydriinae Leach.

3(2) Metatarsomere $\mathrm{V}$ of female shorter than metabasitarsus; metafemur crassate, $3-5 \times$ longer than broad; forewing 2r-rs absent (rarely present, occurring in Derecyrta beechei Smith); head glabrous, shiny and impunctate posterior to ocelli; tarsi with or without pulvilli: Derecyrtini Ashmead.

- Metatarsomere V of female distinctly longer than metabasitarsus; metafemur slender, about $7 \times$ longer than broad; forewing 2r-rs present (i.e., marginal cell divided); head with long, erect setae, integument roughened and typically dull; tarsi with pulvilli: Brachyxiphini Maa.

Paraxiphydria J. Gao, Engel, \& T. Gao, gen. nov. urn:Isid:zoobank.org:act:7463861B-0BE2-4379-88D302D1F9E34A6E

\section{Type species}

Paraxiphydria resinata J. Gao, Engel, \& T. Gao, sp. nov.

\section{Diagnosis}

As for the subfamily (vide supra).

\section{Etymology}

The new genus-group name is a combination of Ancient Greek pará ( $\pi \check{\alpha} \rho \check{\alpha}$, meaning, "near") and Xiphydria Latreille

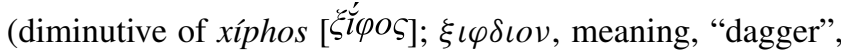
and feminine suffix $-i a[-\breve{\alpha}]]$ ), type genus of the family. The gender of the name is feminine.

Paraxiphydria resinata J. Gao, Engel, \& T. Gao, sp. nov. urn:1sid:zoobank.org:act:4E50875E-AB9D-4423-A391514F69AB3AF6

\section{Diagnosis}

As for the genus (vide supra). 

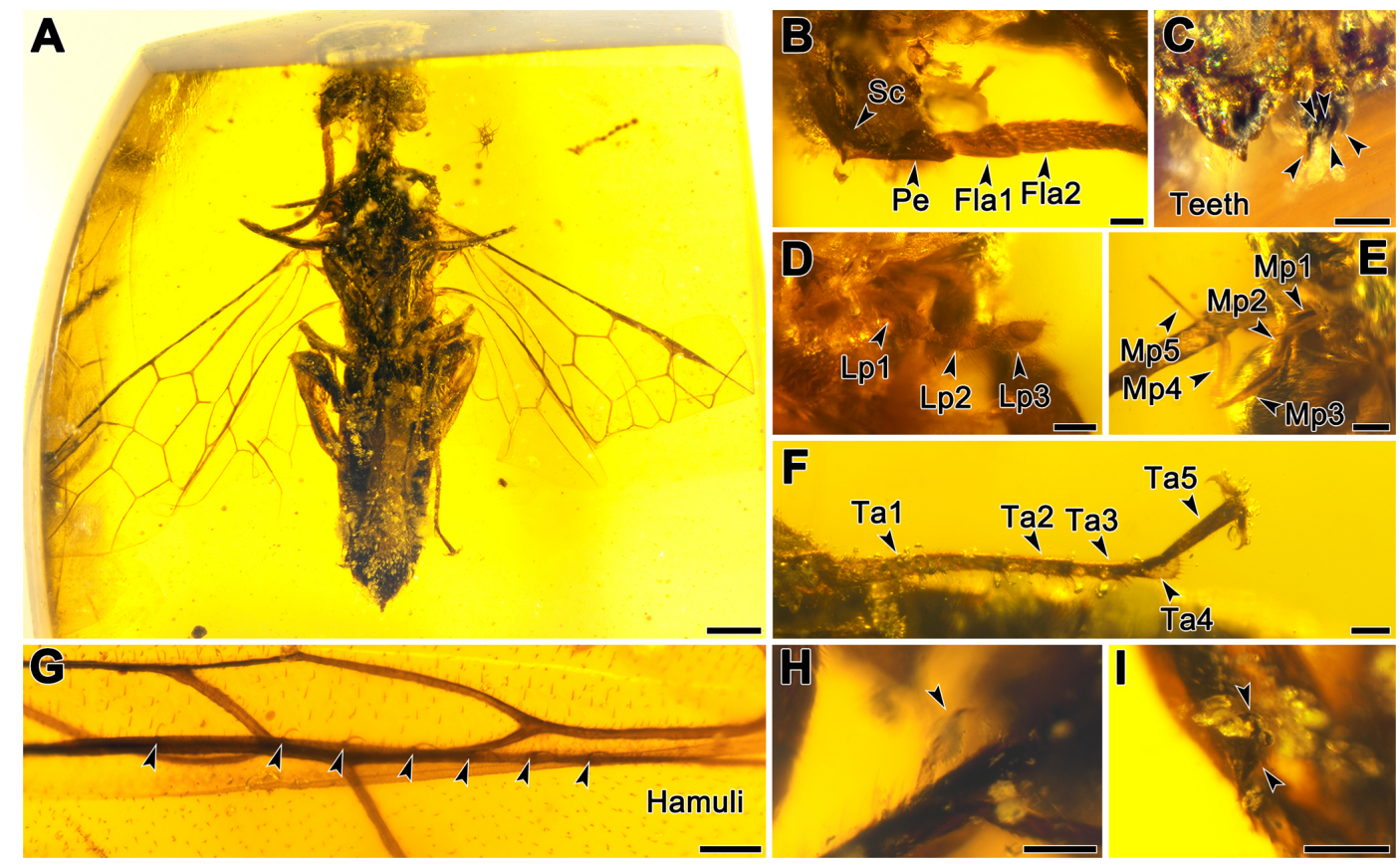

Figure 2. Paraxiphydria resinata gen. et sp. nov. holotype. (a) Photograph of habitus in ventral view. (b) Photograph of antenna in ventral view. (c) Photograph of mandible in anterior view. (d) Photograph of labial palpus in lateral view. (e) Photograph of maxillary palpus in lateral view. (f) Photograph of left metatarsus and metapretarsus. (g) Photograph of right hind wing hamuli. (h) Photograph of right protibial apical spur (see arrow). (i) Photograph of metatibial apical spurs (see arrow). Scale bars: $0.5 \mathrm{~mm}(\mathbf{a}), 0.1 \mathrm{~mm}$ (b-d, f-i), $0.2 \mathrm{~mm}$ (e).

\section{Description}

Total body length $4.9 \mathrm{~mm}$ in lateral view; antenna $1.8 \mathrm{~mm}$ long in ventral view; forewing about $4.0 \mathrm{~mm}$ in length, maximum width $1.3 \mathrm{~mm}$; hind wing about $2.7 \mathrm{~mm}$ in length.

Antenna with 14 antennomeres, antennal length $2.2 \times$ head width; scape $2.1 \times$ as long as pedicel, scape length $2.9 \times$ its width; pedicel length $2.3 \times$ its width; flagellomere I $1.3 \times$ as long as flagellomere II; flagellomeres gradually and slightly tapering distally. In frontal view, face slightly roughened; genal carina absent; mandibles subquadrate, quinquidentate (five teeth) (Fig. 2c); in lateral view, maxillary palpus pentamerous (five palpomeres) (Fig. 2e); labial palpus trimerous (three palpomeres) (Fig. 2d). Sculpturing and setation of head posterior to ocelli not clearly visible.

Thorax narrow, width across tegulae $0.8 \mathrm{~mm}$. Pronotum short and pronotal collar nearly straight anteriorly. Mesoscutum with longitudinal sulcus and notauli strongly impressed, ratio of lengths of prescutum, longitudinal sulcus between notauli and mesoscuto-mesoscutellar sulcus, and mesoscutellum $6: 1: 13$; meso- and metathorax slightly roughened, with parallel reticulations especially on mesoscutellum; transcutal sulcus absent; cenchri small and oval. Protibia with one apical spur (Fig. 2h), mesotibial spur not visible, metatibia with two apical spurs (Fig. 2i); tibiae without preapical spurs; metafemur $5.7 \times$ as long as broad; metabasitarsus length $0.4 \times$ metatarsus and longer than metatarsomere V; tarsi without pulvilli (plantulae); pretarsal claws strongly curved apically, without inner ramus (Fig. 2f), metapretarsal claw similar to mesopretarsal claw.

Abdominal tergum I divided medially, forming subquadrate hemitergites; abdominal segments VIII and IX twice as long as individual lengths of preceding segments; ovipositor short, sheath in dorsal view extending about $0.2 \times$ length of metatibia beyond abdominal apex.

Forewing (Fig. 1c) with abundant microtrichia, membrane hyaline and clear, except slightly infumate in costal space; $\mathrm{C}$ and $\mathrm{R}$ thick, costal space narrower than individual widths of $\mathrm{C}$ and $\mathrm{R}$; pterostigma completely sclerotized throughout; 1r-rs and 2rs-m absent; 2r-rs issuing from middle of pterostigma; $1 \mathrm{Rs}$ short and proclival to $\mathrm{R}$, about $0.6 \times$ as long as $1 \mathrm{M}$, meeting $1 \mathrm{M}$ nearly orthogonally; $2 \mathrm{M}$ present but exceptionally short, $0.1 \times$ as long as Rs+M; 2r-rs slightly proclival; $3+4 \mathrm{M}$ as long as $5 \mathrm{M}$; cell $1 \mathrm{mcu}$ pentagonal, about $1.9 \times$ as long as wide; cell $2 \mathrm{mcu}$ hexagonal, about $1.2 \times$ as long as wide; $2 \mathrm{Cu} 2.0 \times$ as long as $1 \mathrm{Cu} ; 1 \mathrm{cu}-\mathrm{a}$ strongly reclival, nearly $0.5 \times$ as long as $1 \mathrm{Cu} ; 1 \mathrm{~m}-\mathrm{cu}, 3 \mathrm{Cu}$ and $4 \mathrm{Cu}$ subequal; $1 \mathrm{~m}$-cu only slightly distad of the origin of $2 \mathrm{Rs} ; 2 \mathrm{~m}$-cu nearly $0.8 \times$ as long as $5 \mathrm{M}$ and $1.2 \times$ as long as $1 \mathrm{~m}-\mathrm{cu}$.

Hind wing (Fig. 1d) with Sc absent; cell $r$ open; 1Rs about $0.2 \mathrm{~mm}$ in length, nearly as long as $1 \mathrm{M}$; $1 \mathrm{rs}-\mathrm{m}$ about $0.1 \mathrm{~mm}$ in length, reclival and shorter than 1Rs; $1 \mathrm{M}$ straight; 3rs$\mathrm{m}$ and $1 \mathrm{~m}$-cu absent, terminal abscissa ending of $\mathrm{Cu}$ and cu-a well-developed, about $0.3 \mathrm{~mm}$ in length, $1 \mathrm{Cu}$ and cu-a straight. 

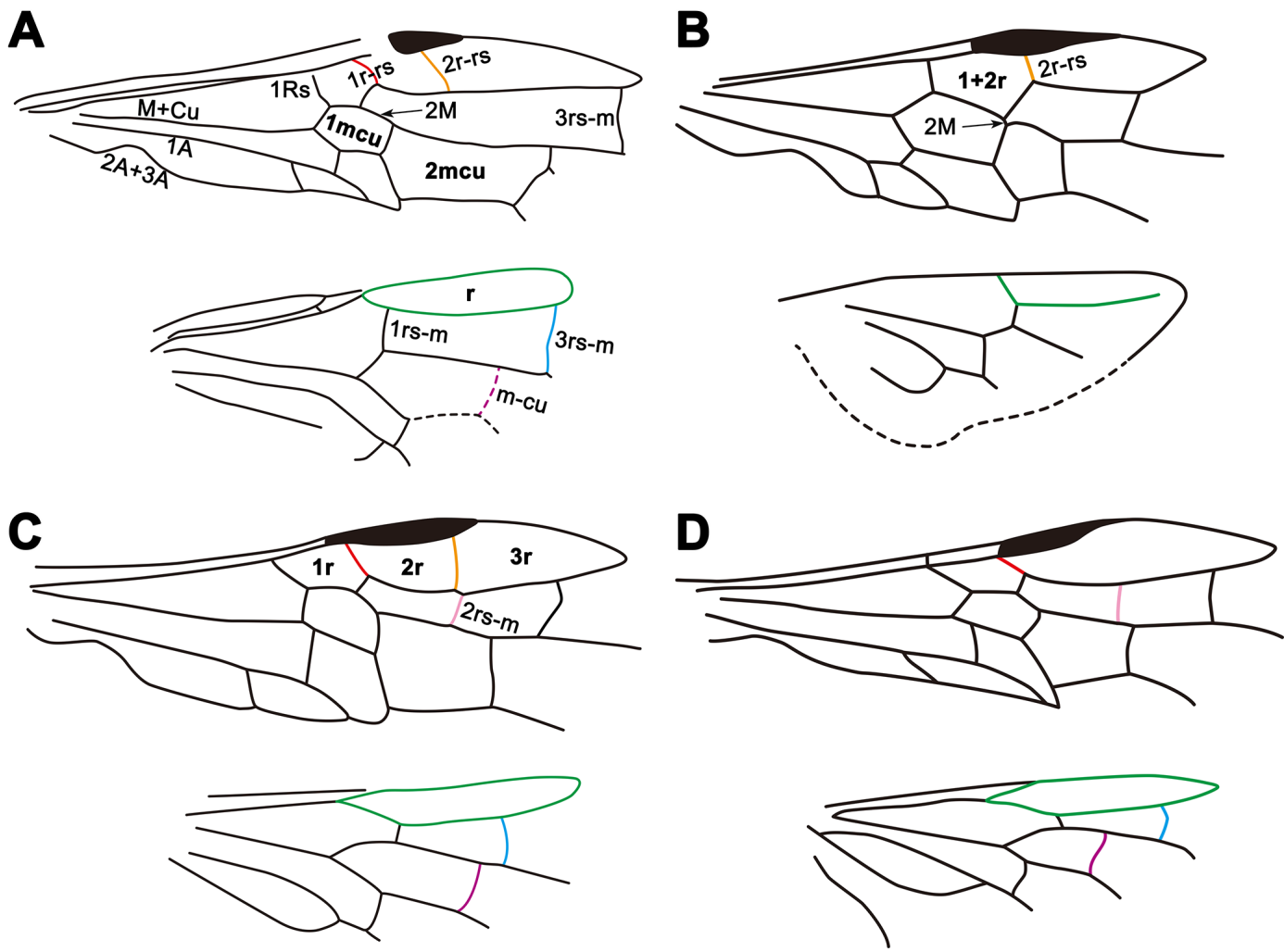

Figure 3. Line drawings of wing venations of Siricidae and Xiphydriidae. (a) Cretosirex xiaoi Wang et al. (Siricidae). (b) Paraxiphydria resinata gen. et sp. nov. (Paraxiphydriinae subfam. nov.). (c) Rhysacephala novacaledonica Jennings et al. (Xiphydriinae). (d) Derecyrta araucariae Mecke (Derecyrtinae).

\section{Material}

Holotype. Female, no. CNU-HYM-MA2015104; earliest Cenomanian (Cretaceous), amber, Hukawng Valley, Kachin, northern Myanmar; College of Life Sciences and Academy for Multidisciplinary Studies, Capital Normal University, Beijing, China.

\section{Etymology}

The specific epithet is a noun combining the Latin noun rēsina (meaning, "resin") and the adjectival suffix àtus (forming adjectives from nouns indicates the possession of a quality).

\section{Discussion}

Paraxiphydria resinata sp. nov., the earliest known Xiphydriidae, is easily recognized as belonging to this family based on its elongate neck and dome-shaped head, as well as other features of the thorax and wing venation (Figs. 1, 2). Although $P$. resinata has some similarities with Derecyrtinae owing to the presence of a single r-rs crossvein in the forewing and the absence of preapical spines on the meso- and metatibiae, as well as the lack of tarsal pulvilli (Smith, 1988), it can be distinguished quite readily based on wing venation and form of the pronotal collar. The absence of 1r-rs and 2rs-m in the forewing, the exceptionally short $2 \mathrm{M}$ present in the forewing, hind wing cell $\mathrm{r}$ open, and 3rs-m and $1 \mathrm{~m}-\mathrm{cu}$ lacking in the hind wing distinguish the fossil from all extant subfamilies.

It is interesting to note that the wing venation of $P$. resinata is somewhat reduced compared to most living xiphydriids and other related families (Fig. 3). In many estimates of Hymenoptera phylogeny, Siricoidea are a sister to Xiphydriidae + Euhymenoptera (e.g., Vilhelmsen, 2001; Sharkey et al., 2012; Malm and Nyman, 2015: although see Peters et al., 2017), and the venation of the fossil is simpler (likely apomorphically) in several details relative to Siricoidea and extant Xiphydriidea. For example, 1r-rs in the forewing and $3 \mathrm{rs}-\mathrm{m}$ and $1 \mathrm{~m}-\mathrm{cu}$ in the hind wing are lacking compared to representatives of Siricidae, Xiphydriinae and Derecyrtinae (Fig. 3), and 2rs-m in the forewing is also absent compared to representatives of Xiphydriinae and Derecyrtinae (Fig. 3). In addition, $2 \mathrm{M}$ is more than half the length of $1 \mathrm{mcu}$ in living and fossil Siricidae (Fig. 3) and less than half the length of $1 \mathrm{mcu}$ but quite distinct in Xiphydriinae and Derecyrtinae (Fig. 3). By contrast, $2 \mathrm{M}$ is scarcely present in $P$. resinata (Figs. 1, 3). The fossil is generally plesiomorphic in most details for the family (e.g., the open hind wing $r$ cell), but 
most venational characters are independent autapomorphies for the subfamily, emphasizing its distinctiveness relative to the modern fauna.

Pollen clusters with 93 pollen grains are preserved near the wood wasp in the amber (Fig. 4a-c). All the pollen grains observed in the clusters are of the same type and are arranged in proximal or distal polar view with the long equatorial axis facing the observer (Fig. 4d). Only a single grain is arranged with the short equatorial axis facing the observer (Fig. 4d, f). The pollen grains are mostly preserved in hydrated to semihydrated form (Fig. 4f, g; 3-dimensional state) but rarely in dehydrated/dry form (Fig. 4e; collapsed, infolded) (see Halbritter et al., 2018, p. 57, Harmomegathic effect). The pollen preserved in hydrated form show a brownish interior (Fig. 4g) that partly obscures the aperture arrangement when observed with DM. The pollen preserved in dry form is yellowish, is more transparent and shows the aperture arrangement more clearly (Fig. 4e). The CLM analysis (Fig. 4k-m) shows that all the pollen grains are equipped with a single sulcus as aperture. Based on the combined DM and CLM analyses we conclude that the pollen grains all appear as monads, they are oblate, the $\mathrm{P} / \mathrm{E}$ ratio is $0.5-0.6$, and the grains are ellipsoid to boat-shaped. The pollen is elliptic in polar view and in equatorial view when the long axis is facing the observer. The pollen is small in size (see Halbritter et al., 2018, p. 57). The long equatorial diameter is 15.6(19) $-22.3 \mu \mathrm{m}$ and the short equatorial diameter is $10-(12.3)-$ $14.7 \mu \mathrm{m}$ in DM (based on measurements from all 93 pollen grains in Fig. $4 \mathrm{~b}, \mathrm{c})$. The polar axis is $8-10 \mu \mathrm{m}$ long in DM (Fig. 4f). The pollen is sulcate, and the sulcus covers most of the distal half of the pollen and is broadly elliptic in outline (CLM; Fig. 4k-m). The exine of the pollen is $0.8-1.2 \mu \mathrm{m}$ thick in DM.

Based on the pollen morphology the fossil pollen is attributed to Cycadopites Wodehouse (Traverse, 2007), a gymnosperm form genus (Balme, 1995). Cycadopites pollen has previously been affiliated with Cycadales, Peltaspermales, Ginkgoales, Czekanowskiales, Pentoxylales and Bennettitales (Balme, 1995; Van, 1971; Taylor et al., 2009; Friis et al., 2011). Still, most of these plant groups can be excluded as the "parent plant" of the pollen based on their occurrence in the fossil record and/or the size of the pollen they are known to produce (e.g., Taylor et al., 2009, and references therein). This is the case with Peltaspermales, Czekanowskiales and Pentoxylales. Peltaspermales occur in Pennsylvanian (Carboniferous) to Triassic sediments, and their pollen is reported to be $23-40 \mu \mathrm{m}$ in diameter. Czekanowskiales have been discovered in Late Triassic to Early Cretaceous sediments, and this group comprises both inaperturate, as well as bisaccate, pollen types, but Ixostrobus (the strobilus of Czekanowskia) contains sulcate pollen grains that are $35-40 \mu \mathrm{m}$ in diameter. Pentoxylales are known from Jurassic to Early Cretaceous sediments, and the pollen of Sahnia (the pollen organ of Pentoxylon) is sulcate and ca. $25 \mu \mathrm{m}$ in diameter (e.g., Taylor et al., 2009). Age-wise this leaves Ginkgoales, Bennet- titales and Cycadales. The Ginkgoales (Ginkgophytes) first appear in Permian sediments and peaked during the Mesozoic, but the group has survived until the present and is currently represented by a single living species, Ginkgo biloba. Fossil pollen attributed to Ginkgoales is sulcate and usually 25-50 $\mu \mathrm{m}$ in diameter (e.g., Tekleva et al., 2007; Zavialova et al., 2011; and references therein). So far there are no reports of in situ fossil Ginkgoales pollen as small as the pollen discovered in the amber presented herein, and the pollen of living Ginkgo is $25-35 \mu \mathrm{m}$ in diameter (Tekleva et al., 2007; Halbritter and Heigl, 2021). Therefore, based on the pollen size we also exclude Ginkgoales. The Bennettitales (or cycadeoids) have been described from Permian to Cretaceous sediments and apparently were widespread and conspicuous from Late Triassic to the mid-Cretaceous but declined during the Late Cretaceous when the angiosperms rapidly diverged (e.g., Taylor et al., 2009; Friis et al., 2011; and references therein). As with the other groups previously discussed, pollen of Bennettitales is sulcate and usually larger than that discovered in the amber specimen under scrutiny; for example, in situ pollen from pollen organs of Weltrichia (Williamsoniaceae) is ca. $46 \mu \mathrm{m}$ in diameter (Taylor et al., 2009). Still, there are reports of in situ pollen of bennettitalean affinity (summarized in Zavialova et al., 2009) that fall within the size and morphological (DM based) range of the pollen discovered in the amber piece presented herein. Theoretically, the pollen observed in the amber could originate from a bennettitalean parent plant, and insect-bennettitalean interactions have previously been suggested based on Cretaceous amber fossils from Spain and Myanmar (Peñalver et al., 2015). The earliest Cycadales records are from the Pennsylvanian (Carboniferous), but the group has survived until the present and currently comprises ca. 330 species in ca. 10 genera in 3 families (e.g., Chaw et al., 2005; Osborne et al., 2012; Salas-Leiva et al., 2013). Pollen from different genera and species of both extinct and extant Cycadales (e.g., Deghan and Dehgan, 1988; Zavialova et al., 2011) is comparable to the fossil pollen discovered in the amber. As an example, the fossil pollen within the amber piece can be compared with pollen of extant Cycas revoluta Thunb. (Fig. 4h$\mathrm{k})$.

The occurrence of the pollen with the wood wasp could well be coincidental as many syninclusions do not have an ecological or biotic association other than having been ensnared by the same resin flow. Nonetheless, pollen is not abundantly dispersed in most pieces of Kachin amber, and its occurrence in the present piece could suggest some association with the wood wasp. Although it remains speculative, it is tantalizing to hypothesize that these pollen grains reflect a gymnospermous (bennettitalean or cycadalean) association for Paraxiphydria. Both the Bennettitales and the Cycadales have been suggested to have had some sort of pollen-related interaction with various insects during the Cretaceous (e.g., Peñalver et al., 2012, 2015; Peris et al., 2015; Cai et al., 2018). Interestingly, the Cycadales are the 


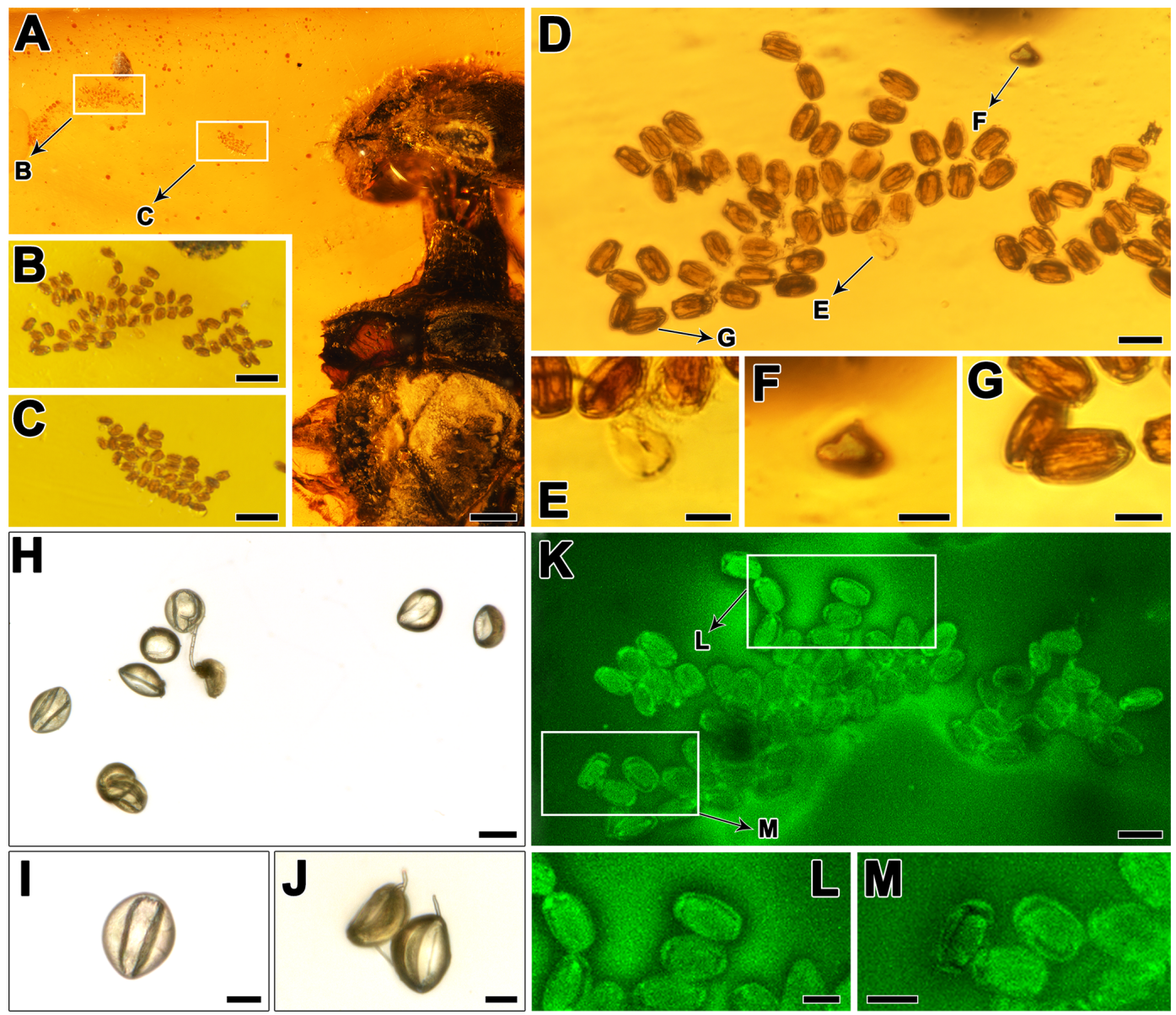

Figure 4. (a) Partial view of Paraxiphydria resinata gen. et sp. nov. and adjacent aggregations of pollen grains. (b) Enlargement of an aggregation of many pollen grains. (c) Enlargement of an aggregation of many pollen grains. (d) Enlargement of (b), showing an aggregation of many pollen grains. (e) Enlargement of (d), showing a single dehydrated/dry pollen grain in distal polar view with a clear sulcus. (f) Enlargement of (d), showing a single (semi-)hydrated pollen grain in equatorial view with the short axis facing the observer. (g) Enlargement of (d), showing a single (semi-)hydrated pollen grain in equatorial view with the long axis facing the observer. (h-j) Extant pollen grains of Cycas revoluta Thunb. (Cycadales: Cycadaceae). (i) Enlargement of a single grain in polar view. (j) Enlargement showing two pollen grains in equatorial view with the long axis facing the observer (upper left) and in oblique polar view (lower right). (k-m) Enlargement of (a), showing an aggregation of many pollen grains under confocal laser microscope. (l-m) Enlargement of (k), showing several pollen grains in distal polar view; note the large elliptic sulcus that covers most of the distal half of the pollen. Scale bars, $0.2 \mathrm{~mm}(\mathbf{a}), 0.05 \mathrm{~mm}(\mathbf{b}, \mathbf{c})$, $0.02 \mathrm{~mm}(\mathbf{d}, \mathbf{h}, \mathbf{k}), 0.01 \mathrm{~mm}(\mathbf{e}-\mathbf{g}, \mathbf{i}, \mathbf{j}, \mathbf{l}, \mathbf{m})$.

only extant gymnosperm group (except for some Ephedra; Bolinder et al. 2016) that are insect pollinated and are visited by various Coleoptera, Lepidoptera and Thysanoptera (e.g., Toon et al., 2020). Today xiphydriids are associated with angiosperms, and one could hypothesize that Paraxiphydria retained a plesiomorphic ecological relationship with gymnosperms, much like Siricoidea and the presumed ground-plan condition for their broader clade. Clearly, if stem-xiphydriids were restricted to angiosperms like their modern relatives, they would have had few host plants in the Early Cretaceous as gymnosperms were dominant at the time. As Xiphydriidae must predate the mid-Cretaceous (based on the current fossil as well as divergence estimations; e.g., Peters et al., 2017), stem-xiphydriids would have had to have originated in association with gymnosperms and then shifted to angiosperms at some time during the Cretaceous. Similar shifts have been suggested for other insect groups (e.g., Peris et al., 2017). As gymnosperms dwindled in the Late Cretaceous and angiosperms continued to diversify after their explosive radiation in the mid-Cretaceous, crown-Xiphydriidae specialized on angiosperm hosts. Naturally, many angiosperm-associated species are entombed in Kachin amber (e.g., Grimaldi and Ross, 2017), and the cooccurrence of the pollen and wasp in a gymnospermous resin may not reflect paleobiology. Paraxiphydria could have been associated with early angiosperms, and it will take continued exploration of Cretaceous and older deposits of additional fossil wood wasps in order to more fully develop hypotheses 
regarding their evolution and changing host-plant affiliations through time.

Data availability. The new material included in the paper is deposited and accessible in the Capital Normal University, Beijing, China, and all data are included in the description.

Author contributions. MSE and TPG designed the study. JG, MSE and TPG contributed the descriptive section (including preparation of the illustration). LG and FG provided the palynological and paleobotanical sections, JG and DR provided references and materials. All authors discussed the results and revised the manuscript.

Competing interests. The contact author has declared that neither they nor their co-authors have any competing interests.

Disclaimer. Publisher's note: Copernicus Publications remains neutral with regard to jurisdictional claims in published maps and institutional affiliations.

Acknowledgements. We thank the editorial board of Fossil Record and in particular Alexander Schmidt and Florian Witzmann. We are grateful to Jia-Xi Liu, Xin-Ci Cui, Si-Min Ren, Zi-Ming Hu and Xiang-Bo Guo of the Capital Normal University for their valuable comments and suggestions for the manuscript and Yan-Jie Zhang and Xianyong Sheng of the Capital Normal University for their help in confocal microscope photography. We express our gratitude to the anonymous referee for the friendly but critical review of the manuscript. In this study, we reported one xiphydriid specimen (CNU-HYM-MA2015104) preserved in a piece of Kachin amber: CNU009447. It was acquired by Fangyuan Xia before 2013 and donated for this study in 2015 .

Financial support. Dong Ren was supported by grants from the National Natural Science Foundation of China (nos. 31730087 and 32020103006). Taiping Gao was supported by the National Natural Science Foundation of China (31872277) and a project supported by the Fok Ying-Tong Education Foundation for Young Teachers in the Higher Education Institutions of China (171016). The work of Friðgeir Grímsson was funded by the Austrian Science Fund (FWFs), project number P34303-B.

Review statement. This paper was edited by Alexander Schmidt and reviewed by two anonymous referees.

\section{References}

Aguiar, A. P., Deans, A. R., Engel, M. S., Forshage, M., Huber, J. T., Jennings, J. T., Johnson, N. F., Lelej, A. S., Longino, J.

T., Lohrmann, V., Mikó, I., Ohl, M., Rasmussen, C., Taeger, A., and Yu, D. S. K.: Order Hymenoptera, Zootaxa, 3703, 51-62, https://doi.org/10.11646/zootaxa.3703, 2013.

Balme, B. E.: Fossil in-situ spores and pollen grains: an annotated catalogue, Rev. Palaeobot. Palyno., 87, 81-323, https://doi.org/10.1016/0034-6667(95)93235-X, 1995.

Benson, R. B.: Classification of the Xiphydriidae (Hymenoptera), T. Roy. Ent. Soc. London, 105, 151-162, https://doi.org/10.1111/j.1365-2311.1954.tb00781.x, 1954.

Bolinder, K., Humphreys, A. M., Ehrlén, J., Alexandersson, R., Ickert-Bond, S., and Rydin, C.: From near extinction to diversification by means of a shift in pollination mechanism in the gymnosperm relict Ephedra (Ephedraceae, Gnetales), The Botanical Journal of the Linnean Society, 180, 461-477, 2016.

Cai, C., Escalona, H. E., Li, L., Yin, Z., Huang, D., and Engel, M. S.: Beetle pollination of Cycads in the Mesozoic, Current Biol., 28, 2806-2812, 2018.

Chaw, S.-M., Walters, T. W., Chang, C.-C., Hu, S.-H., and Chen, S.-H.: A phylogeny of cycads (Cycadales) inferred from chloroplast matK gene, trnK intron, and nuclear rDNA ITS region, Mol. Phylogenet. Evol., 37, 214-234, 2005.

Cruickshank, R. D. and Ko, K.: Geology of an amber locality in the Hukawng valley, Northern Myanmar, J. Asian Earth Sci., 21, 441-445, 2003.

Dehgan, B. and Dehgan, N. B.: Comparative pollen morphology and taxonomic affinities in Cycadales, Am. J. Bot., 75, 15011516, 1988.

Friis, E. M., Crane, P. R., and Pedersen, K. R.: Early flowers and angiosperm evolution, Cambridge University Press, Cambridge, UK, 596 pp., https://doi.org/10.1017/CBO9780511980206, 2011.

Grimaldi, D. A. and Ross, A. J.: Extraordinary Lagerstätten in amber, with particular reference to the Cretaceous of Burma, in: Terrestrial Conservation Lagerstätten: Windows into the Evolution of Life on Land, edited by: Fraser, N. C. and Sues, H.-D., Dunedin Press, Edinburgh, UK, 287-342, 2017.

Halbritter, H. and Heigl, H.: Ginkgo biloba, in: PalDat - A palynological database, available at: https://www.paldat.org/pub/ Ginkgo_biloba/305256, last access: 28 October 2021.

Halbritter, H., Ulrich, S., Grímsson, F., Weber, M., Zetter, R., Hesse, M., Buchner, R., Svojtka, M., and Frosch-Radivo, A.: Illustrated pollen terminology, 2 Edn., Springer, p. 483, https://doi.org/10.1007/978-3-319-71365-6, 2018.

Jennings, J. T., Austin, A. D., and Schiff, N. M.: Rhysacephala novacaledonica sp. nov. (Hymenoptera: Xiphydriidae), the first xiphydriid woodwasp from New Caledonia, Zootaxa, 1516, 23-30, https://doi.org/10.11646/zootaxa.1516.1.2, 2007.

Kajimura, H.: Discovery of mycangia and mucus in adult female xiphydriid woodwasps (Hymenoptera: Xiphydriidae) in Japan, Ann. Entomol. Soc. Am., 93, 312-317, https://doi.org/10.1603/00138746(2000)093[0312:DOMAMI]2.0.CO;2, 2000.

Maa, T.: A synopsis of Asiatic Siricoidea with notes on certain exotic and fossil forms (Hymenoptera Symphyta), Musée Heude, Notes d'Entomologie Chinoise, 13, 11-189, 1949.

Malm, T. and Nyman, T.: Phylogeny of the symphytan grade of Hymenoptera: new pieces into the old jigsaw(fly) puzzle, Cladistics, 31, 1-17, https://doi.org/10.1111/cla.12069, 2015.

Mecke, R., Barbosa, M. S., and Engels, W.: A new Brazilian sawfly, Derecyrta araucariae spec. nov. (Hymenoptera: Xiphydriidae), 
associated with Araucaria angustifolia (Bert.) O. Kuntze, J. Kansas Entomol. Soc., 73, 177-182, 2000.

Osborne, R., Calonje, M., Hill, K. D., Stanberg, L., and Stevenson, D. W.: The World list of cycads, Mem. New York Botan. G., 106, 480-510, 2012

Peñalver, E., Arillo, A., la Fuente, R. P., Ricco, M. L., Declòs, X., Barrón, E., and Grimaldi D. A.: Long-proboscid flies as pollinators of Cretaceous gymnosperms, Current Biol., 25, 1917-1923, 2015.

Peñalver, E., Labandeira, C. C., Barrón, E., Delclòs, X., Nel, P., Nel, A., Tafforeau, P., and Soriano, C.: Thrips pollination of Mesozoic gymnosperms, P. Natl. Acad. Sci. USA, 109, 8623-8628, 2012.

Peris, D., la Fuente, R. P., Peñalver, E., Delclòs, X., Barrón, E., and Labandeira, C. C.; False blister beetles and the expansion of gymnosperm-insect pollination modes before angiosperm dominance, Current Biol., 27, 897-904, 2017.

Peters, R. S., Krogmann, L., Mayer, C., Donath, A., Gunkel, S., Meusemann, K., Kozlov, A., Podsiadlowski, L., Petersen, M., Lanfear, R., Diez, P. A., Heraty, J., Kjer, K. M., Klopfstein, S., Meier, R., Polidori, C., Schmitt, T., Liu, S., Zhou, X., Wappler, T., Rust, J., Misof, B., and Niehuis, O.: Evolutionary history of the Hymenoptera, Current Biol., 27, 1013-1018, https://doi.org/10.1016/j.cub.2017.01, 2017.

Punt, W., Hoen, P. P., Blackmore, S., Nilsson, S., and Le Thomas, A.: Glossary of pollen and spore terminology, Review Palaeobot. Palynol., 143, 1-81, https://doi.org/10.1016/j.revpalbo.2006.06.008, 2007.

Rasnitsyn, A. P.: Origin and evolution of the lower Hymenoptera, Transactions of the Paleontological Institute, Academy of Sciences of the USSR, 123, 1-196, 1969 (in Russian).

Rasnitsyn, A. P.: Origin and evolution of the Hymenoptera, Transactions of the Paleontological Institute, Academy of Sciences of the USSR, 174, 1-192, 1980 (in Russian).

Riek, E. F.: The Australian Xiphydriidae (Hymenoptera: Symphyta), Aust. J. Zool., 3, 281-285, https://doi.org/10.1071/ZO9550281, 1955.

Salas-Leiva, D., Meerow, A. W., Calonje, M., Griffith, M. P., Francisco-Ortega, J., Nakamura, K., Stevenson, D. W., Lewis, C. E., and Namoff, S.: Phylogeny of the cycads based on multiple single-copy nuclear genes: congruence of concatenated parsimony, likelihood and species tree inference methods, Ann. Bot.London, 112, 1263-1278, 2013.

Sharkey, M. J., Carpenter, J. M., Vilhelmsen, L., Heraty, J. M., Liljeblad, J., Dowling, P. G. A., Schulmeister, S., Murray, D., Deans, R. A., Ronquist, F., Krogmann, L., and Wheeler, C. W.: Phylogenetic relationships among superfamilies of Hymenoptera, Cladistics, 28, 80-112, https://doi.org/10.1111/j.10960031.2011.00366.x, 2012.
Shi, G., Grimaldi, D. A., Harlow, G. E., Wang, J., Wang, J., Yang, M., Lei, W., Li, Q., and Li, X.: Age constraint on Burmese amber based on U-Pb dating of zircons, Cretaceous Res., 37, 155-163, https://doi.org/10.1016/j.cretres.2012.03.014, 2012.

Smith, D. R.: A synopsis of the sawflies (Hymenoptera: Symphyta) of America south of the United States: introduction, Xyelidae, Pamphiliidae, Cimbicidae, Diprionidae, Xiphydriidae, Siricidae, Orussidae, Cephidae, Syst. Entomol., 13, 205-261, https://doi.org/10.1111/j.1365-3113.1988.tb00242.x, 1988.

Taeger, A., Blank, S. M., and Liston, A. D.: World cata$\log$ of Symphyta (Hymenoptera), Zootaxa, 2580, 1-1064, https://doi.org/10.11646/zootaxa.2580.1.1, 2010.

Taylor, T. N., Taylor, E. L., and Krings, M.: Paleobotany, The Biology and Evolution of Fossil Plants, 2 Edn., Elsevier/Academic Press, 1230 pp., 2009.

Tekleva, M. V., Polevova, S. V., and Zavialova, N. E.: On some peculiarities of sporoderm in members of the Cycadales and Ginkgoales, Paleontol. J., 41, 1162-1178, 2007.

Toon, A., Terry, L. I., Tang, W., Walther G., and Cook, L. G.: Insect pollination of cycads, Austral. Ecol., 45, 1033-1058, 2020.

Traverse, A.: Paleopalynology, Springer Science \& Business Media, Heidelberg, Germany, 813 pp., https://doi.org/10.1007/9781-4020-5610-9, 2007.

Van Konijnenburg-van Cittert, J. H. A.: In situ gymnosperm pollen from the Middle Jurassic of Yorkshire, Acta Bot. Neerl., 20, 197, 1971.

Vilhelmsen, L.: Phylogeny and classification of the extant basal lineages of the Hymenoptera (Insecta), Zool. J. Linn. Soc.-Lond., 131, 393-442, https://doi.org/10.1111/j.10963642.2001.tb01320.x, 2001

Yu, T., Kelly, R., Mu, L., Ross, A., Kennedy, J., Broly, P., Xia, F., Zhang, H., Wang, B., and Dilcher, D.: An ammonite trapped in Burmese amber, P. Natl. Acad. Sci. USA, 116, 11345-11350, https://doi.org/10.1073/pnas.1821292116, 2019.

Zavialova, N., Van Konijnenburg-van Cittert, J., and Zavada, M.: The pollen ultrastructure of Williamsoniella coronata Thomas (Bennettitales) from the Bajocian of Yorkshire, Int. J. Plant Sci., 170, 1195-1200, 2009.

Zavialova, N., Markevich, V., Bugdaeva, E., and Oltevova, S.: The ultrastructure of fossil dispersed monosulcate pollen from the Early Cretaceous of Transbaikalia, Russia, Grana, 50, 182-201, 2011. 